\title{
Microphthalmus mahensis sp.n. (Annelida, Phyllodocida) together with an annotated key of the genus
}

\author{
Wilfried Westheide
}

Received: 16 February 2012/Revised: 24 August 2012/Accepted: 24 September 2012/Published online: 18 November 2012 (C) Springer-Verlag Berlin Heidelberg and AWI 2012

\begin{abstract}
An interstitial polychaete, Microphthalmus mahensis, new species (Phyllodocida), is described from sand sediments of a coral reef flat of the Seychelles island Mahé. A comprehensive discussion includes a complete list of all 38 valid Microphthalmus species, and a key together with critical remarks on problematic species and subspecies.
\end{abstract}

Keywords Indian Ocean - Seychelles · Interstitial fauna · Polychaeta · Taxonomy

\section{Introduction}

Two short expeditions to the Seychellan island Mahé in 1999 and 2000 revealed a considerably diverse fauna of interstitial polychaetes (Böggemann et al. 2003), of which a number of species have already been determined and published (Westheide 2000a, b; 2001; Westheide and HassCordes 2001; Böggemann and Westheide 2004). As in most of such sandy shallow water habitats around the world, the fauna also comprises a species of the genus Microphthalmus Mecznikow, 1865, confirming the already known highly cosmopolitan distribution of this taxon, from Antarctica (Bick 1997/1998) to various tropical coastal areas. The genus - by the way established by a Nobel Prize winner of 1908-traditionally has been included in the Hesionidae, but possibly may represent a separate new taxon within Phyllodocida (Pleijel and Dahlgren 1998; Rouse and Pleijel 2001).

Communicated by H.-D. Franke.

W. Westheide $(\square)$

Gerhart-Hauptmann-Straße 3, 49134 Wallenhorst, Germany

e-mail: westheide@biologie.uni-osnabrueck.de
During the past more than 145 years since $M$. sczelkowii was published, 38 valid species have been described. In addition, four subspecies have been erected. Of these, one is considered to be a true species and therefore has been included in the present list of species. The other three are doubtful. An even higher number of Microphthalmus species can be expected. Many of them have not yet been recognized, because of their small size and their relatively few distinguishing features, for example, in chaetation. Very often, the most useful diagnostic characters are not available, since the animals were immature when sampled. Microphthalmus species are exclusively simultaneous hermaphrodites, and their unique male copulatory organs feature the most suitable species-specific characters (Bobretzky 1870; Alikunhi 1948; Westheide 1967, 1988; Clausen 1986). These, however, are formed only during a relatively short period of the animals' life, and the lack of such details unfortunately has led to a high number of imperfect species descriptions without these details.

Separating this large batch of species in a conclusive key is rather difficult. Nevertheless, it seemed appropriate to avoid a split into two or more genera, since this would probably lead to paraphyletic taxa.

The new species belongs to the large subgroup possessing a fimbriate (fringed or papillated) anal plate. Each of the paired male genital organs in the anterior part of the body is equipped with a bundle of probably intracellular copulatory stylets (Westheide 1979). So far, this peculiar structure was found only in two (or three) other species, which, however, differ distinctly in their notopodial chaetation pattern: three simple chaetae, including a pectinate one. The present description has been the reason for giving an annotated up-to-date list of the Microphthalmus species together with a key based on morphological features. 
Diagnosis of the genus Microphthalmus

Prostomium with 2-3 filiform antennae, and 2 filiform sensory palps. Median antenna, when present, medially positioned on the prostomium. Three achaetous tentacular segments, each with two pairs of filiform tentacular cirri. No distinct ceratophores, palpophores or cirrophores. Parapodia subbiramous. Pygidium with two dorsolateral anal cirri and a ventral anal plate. Tubular pharynx with papillate margin, without jaws. Hermaphroditic, with male segments in the anterior and female segments in the posterior part of the body.

Description of Microphthalmus mahensis n.sp.

Figs. 1, 2 and 3
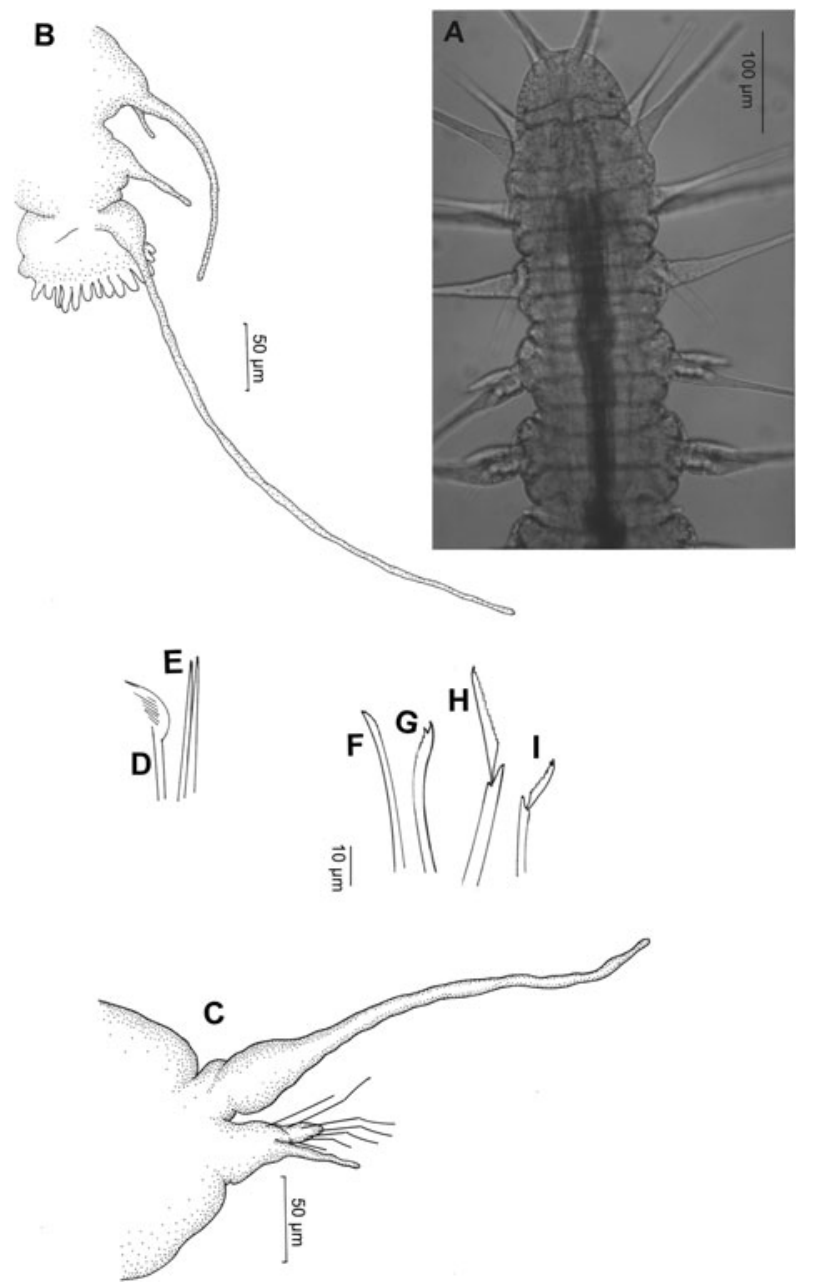

Fig. 1 Microphthalmus mahensis n.sp. a Anterior end. Micrograph of a mature live specimen. b Posterior end with anal plate; only one anal cirrus. c Parapodium from a midbody chaetiger, anterior view. d-f Notopodial chaetae: d Pectinate chaeta. e The two straight chaetae. f-i Neuropodial chaetae: f Superiormost simple chaeta. g Inferiormost simple chaeta. h Supraacicular compound chaeta with long blade. i Subacicular compound chaeta with short blade
Type locality and material examined Indian Ocean, Island of Mahé, Republic of Seychelles: $4^{\circ} 47^{\prime} \mathrm{S}, 55^{\circ} 31^{\prime} \mathrm{E}$. Reef flat in front of the east coast beach "Anse Forbans", in extremely clean coarse sand shallow subtidal areas. February 1999 (10 fixed specimens, 4 living specimens) and March 2000 (5 fixed specimens, 6 living specimens).

Type material Holotype is a complete whole-mounted specimen with 26 chaetigerous segments, deposited in the Senckenberg Museum Frankfurt/Main (SMF 19445). There are five complete and one incomplete paratype specimens in alcohol (SMF 19446, 19447, 19448).

Etymology The species name refers to the type locality on the island of Mahé.

Diagnosis Anal lobe with fimbriate papillae; three notopodial chatae including a pectinate one; male copulatory organs each with a bundle of stylets.

Description The largest specimen has a length of $3.4 \mathrm{~mm}$; number of chaetigerous segments in mature specimens 22-26. Width about 130-145 $\mu \mathrm{m}$ between parapodia in the anterior and middle part of the body. The animals are transparent, without colour pattern.

Prostomium wider than long, with almost semicircular anterior margin (Figs. 1a, 2a). Prostomial appendages filiform, almost smooth: two dorsal antennae (ca. $100 \mu \mathrm{m}$ ), two similar slightly shorter ventral sensory palps, unpaired median antenna originating at the posterior border of the prostomium, slightly shorter (ca. $80 \mu \mathrm{m}$ ) than paired antennae, reaching exactly to the anterior margin of the prostomium.

Ovoid nuchal organs typical for the genus (Purschke 1997) near base of the first pair of dorsal tentacular cirri (Fig. 2a). One pair of pigmented lateral eye spots somewhat behind the middle of the prostomium (Figs. 1a, 2a).

Typically three achaetous segments with paired tentacular cirri, the dorsal ones of the third segment being the longest (ca. $205 \mu \mathrm{m}$ ); ventral cirri of this segment have a length of $60 \mu \mathrm{m}$ only (Fig. 2a). The following chaetigerous segments almost identical, except for the first one, which lacks notopodial chaetae, and the two or three most posterior ones, which are more or less incomplete and gradually decrease in width (Fig. 2b). Filiform dorsal notopodial cirri, with bulbous base; length in the middle of the body about $240 \mu \mathrm{m}$, that is, longer than the body width and extending beyond the neuropodial lobe (Fig. 1c).

Notopodium with three tiny simple chaetae, which may slightly project from its base: one pectinate chaeta with parallel teeth (their number could not be determined with 
Fig. 2 Microphthalmus mahensis n.sp. Micrographs of live specimens. a Anterior end with prostomium, three tentacular segments and first chaetiger. es eye spot, $n u$ nuchal organ, $p p$ pharyngeal papillae. b Posterior end with incompletely developed posteriormost chaetigers, pygidium and fimbriate anal plate
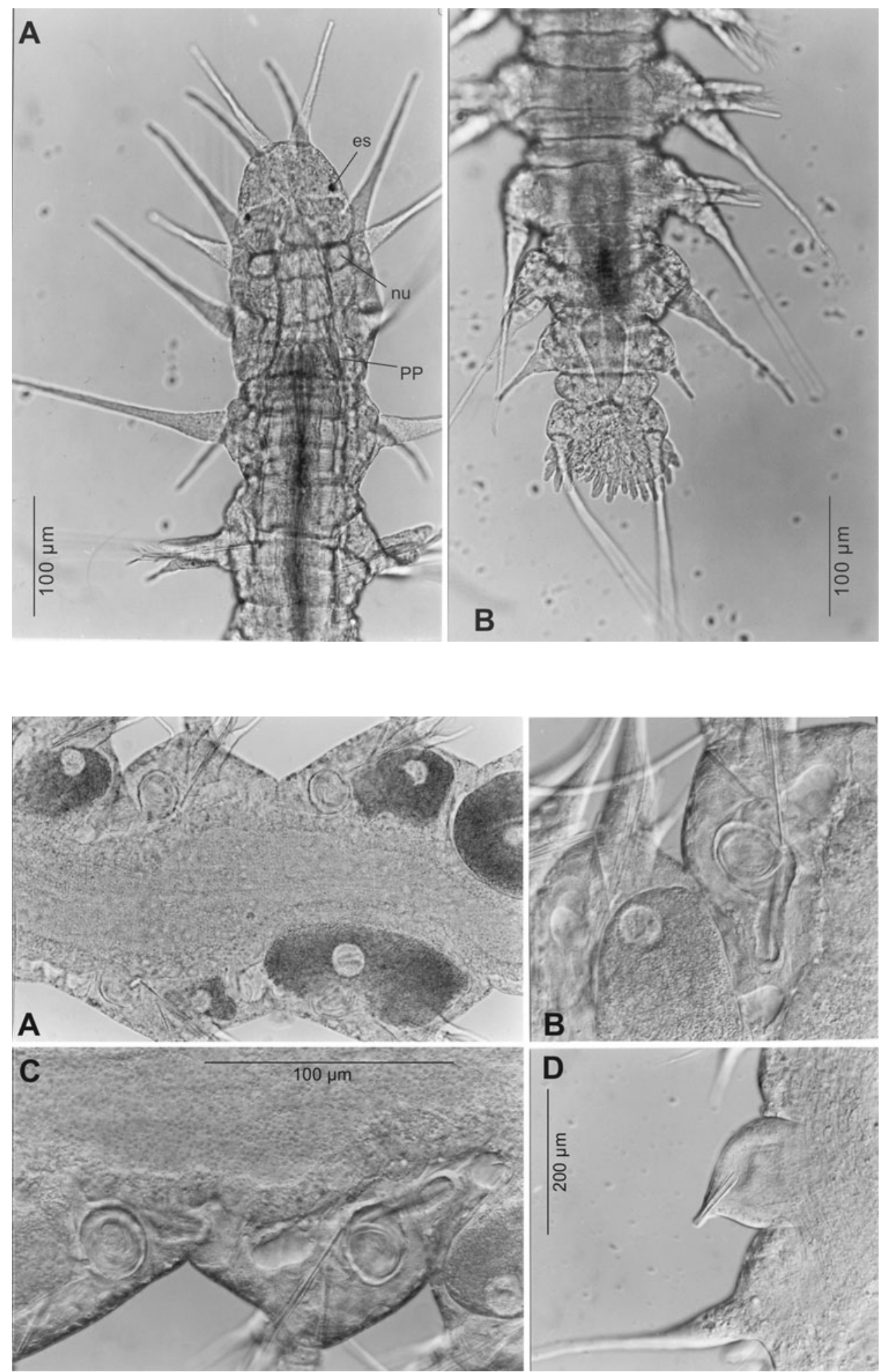

Fig. 3 Microphthalmus mahensis n.sp. Micrographs of live specimens. Genital organs. a Posterior body region with oocytes and sperm-filled receptacles. b, c Sperm-filled receptacles. d Male papilla between second and third chaetiger, projected; with bundle of copulatory stylet rods certainty) (Fig. 1d) and two straight ones, both tapering, but one distinctly longer and slightly wider than the other one (Fig. 1e). It is difficult to decide which one may be a notopodial acicula. Neuropodial chaetal bundle arranged above and below the thin straight acicula consisting of 4-5 compound falcigers and two or three simple chaetae. Blades of varying lengths: up to $22 \mu \mathrm{m}$ in the dorsal supraacicular ones (Fig. 1h), distally slightly serrated; bifid tip difficult to detect. Shortest blades of subacicular compounds (Fig. 1j) about half as long as the long superior 
ones, subdistally finely serrated and distinctly bifid. One superiormost (=dorsal) simple chaeta (Fig. 1f), almost straight, subdistally serrated and probably tapering. One (rarely two) inferiormost (=ventral) simple chaeta, distally slightly bent, distinctly bifid, subdistally indistinctly serrated (Fig. 1g).

Pygidium short, about $100 \mu \mathrm{m}$ wide. Two relatively long $(400-450 \mu \mathrm{m})$ dorsolaterally inserted filiform anal cirri with distinctly swollen base. Anal plate (Figs. 1b, 2b) relatively narrow, not much wider than the pygidial base; posterior margin fimbriate with relatively few (about 15) short papillae.

Most of the specimens with over 20-21 chaetigers revealed details of their hermaphroditic genital organs: between second and third pair of parapodia paired papillae each with a conical bundle of probably intracellular copulatory stylet rods (Fig. 3d) (see Westheide 1979) (length of bundle $92 \mu \mathrm{m}$, number of rods not detectable). Maturing oocytes from chaetiger 14 backwards (Fig. 3a-c). In each of the chaetigers 15-21 one pair of spherical receptacles with ciliated duct containing a ball of filiform sperm (Fig. 3a-c).

Remarks Microphthalmus mahensis n.sp. shares great similarities with M. similis of Bobretzky, 1870. Besides its minor body size, the new species differs in possessing three notopodial chatae (Table 1).

\section{Taxonomic remarks}

1. Webster and Benedict (1887) described Podarke aberrans from the US east coast. Their type material obviously consisted of specimens varying in size and belonging to separate species (Westheide 1967; Riser 2000). Southern (1914) transferred this species to the genus Microphthalmus, when classifying specimens from Ireland as Microphthalmus aberrans. Riser (2000) reinvestigated the entire type material from the US east coast and distributed it into three species, two of which were new to science: M. aggregatus (see above) and M. pettiboneae (formerly M. aberrans). For the third one (a species with fimbriate anal plate!), he left the name "aberrans". This "resolution" causes a certain taxonomic confusion, since Riser's new M. aberrans is completely different from the old one. Identity of the European M. aberrans sensu Westheide (1967) with M. pettiboneae (Riser 2000) has still to be proven by molecular methods; morphological identity of European specimens from the North Sea coast with specimens from New England recorded by Pettibone (1963) was already doubted (Westheide 1967, p. 126).
2. Hartman (1939) described Hesionella mccullochae from southern California. Rouse and Pleijel (2001) seem to have information that it is a Microphthalmus species. Hesionella pacifica Friedrich, 1956 [= Fridericiella pacifica (Friedrich) n.nom. by HartmannSchröder (1959, p. 74), see also Laubier (1967)], however, belongs without doubt to Microphthalmus as the figures in the description clearly demonstrate (Friedrich 1956). It is therefore included in this list of species, but not into the key because of the insufficient details in figures and text of the original description.

3. Microphthalmus listensis Westheide, 1967, M. carolinensis Westheide and Rieger, 1987 and M. nahantensis Westheide and Rieger, 1987 form a complex of cryptic transatlantic species. Their external morphology, chaetae, copulatory organs and other features are highly identical, yet it is clearly possible to separate the three species morphologically (Westheide and Rieger 1987). Molecular methods congruently separated the species and demonstrated the two American forms (M. carolinensis and M. nahantensis) to be more closely related to each other than to the European M. listensis (Westheide and Schmidt 2003).

4. Microphthalmus southerni Westheide, 1967 was erected because of the considerable differences in the design of M. sczelkowii recorded from the Irish coast by Southern (1914) and that of animals from the locus typicus around the North Sea island of Helgoland: shape of the posterior margin of the prostomium, details of the pectinate notopodial chaeta and trifid end of the neuropodial compounds. Since, however, no specimen with the specific attributes of Southern's description has yet been recorded neither by the author nor by another investigator, as far is known, it cannot be totally ruled out that these supposed differences result from a possible incorrectness of Southern's (1914) drawings.

5. Microphthalmus hartmanae pacificus Yamanishi, 1984 is indeed very close to its nominate species (Westheide, 1977). However, it differs clearly in several characters, for example, with a length of up to $9 \mathrm{~mm}$, it is considerably longer; the notopodial acicula is similar to the simple notochaetae; the neuropodial pectinate chaeta has a higher number of teeth; the distal parts of the compounds are slightly serrated; the anal cirri are much shorter (Yamanishi 1984), and the prostomium appears to have a clearly different shape. These differences unambiguously justify ranking the subspecies as a separate valid species. Since, however, the subspecies' name is 
Table 1 Chronological list of valid Microphthalmus species

\begin{tabular}{|c|c|c|c|}
\hline Species & Author and year of description & Locus typicus & $\begin{array}{l}\text { Taxonomic } \\
\text { remarks }\end{array}$ \\
\hline sczelkowii & Mecznikow, 1865 & Helgoland, North Sea & \\
\hline similis & Bobretzky, 1870 & Black Sea & (6) \\
\hline fragilis & Bobretzky, 1870 & Black Sea & \\
\hline aberrans & (Webster and Benedict, 1887) & New England, Atlantic & (1) \\
\hline urofimbriatus & Alikunhi, 1948 & Madras coast, India & \\
\hline pacificus & (Friedrich, 1956) & Peru, Pacific & (2) \\
\hline aciculata & Hartmann-Schröder, 1962a & Peru, Pacific & \\
\hline ancistrosylliiformis & Hartmann-Schröder, 1962b & Dichato, Chile, Pacific & \\
\hline monilicornis & Hartmann-Schröder, 1962a & Peru, Pacific & \\
\hline listensis & Westheide, 1967 & North Sea coast, Germany & (3) \\
\hline southerni & Westheide, 1967 & Clare Island, Irish Sea & (4) \\
\hline tyrrhenicus & Zunarelli Vandini, 1967 & Leghorn coast, Italy, Mediterranean Sea & \\
\hline riojai & Reish, 1968 & Baja California, Pacific & \\
\hline arenarius & Westheide, 1973 & Bermuda, Atlantic & \\
\hline bermudensis & Westheide, 1973 & Bermuda, Atlantic & \\
\hline indefatigatus & Westheide, 1974 & Galapagos Islands, Pacific & \\
\hline bifurcatus & Hartmann-Schröder, 1974b & Skagerrak, North Sea & \\
\hline hartmanae & Westheide, 1977 & Florida, USA & \\
\hline japonicus comb.nov. & Yamanishi, 1984 & Seto, Japan, North Pacific & (5) \\
\hline hamosus & Westheide, 1982 & Florida, USA & \\
\hline paraberrans & Hartmann-Schröder, 1982 & Cervantes, Australian West coast & \\
\hline westheidei & Hartmann-Schröder, 1982 & Fremantle, Australian West coast & \\
\hline pseudoaberrans & Campoy and Viéitez, 1982 & Northern Spain, Atlantic & (7) \\
\hline ephippiophorus & Clausen, 1986 & Raunefjorden, Norway & \\
\hline carolinensis & Westheide and Rieger, 1987 & North Carolina, US Atlantic coast & (3) \\
\hline nahantensis & Westheide and Rieger, 1987 & Massachusetts, US Atlantic coast & (3) \\
\hline coustalini & Fournier, 1991 & Port Edward, Can. Pacific coast & \\
\hline hystrix & Fournier, 1991 & Puget Sound, US Pacific coast & \\
\hline simplicichaetosus & Westheide and Purschke, 1992 & Puget Sound, US Pacific coast & \\
\hline biantennatus & Wu, Zhao and Westheide, 1993 & China, Yellow Sea & \\
\hline onychophorus & Westheide, 1994 & Chile, Antofagasta & \\
\hline riseri & Westheide, 1994 & New Zealand, North Island & \\
\hline antarcticus & Bick, 1998 & King George Island, Antarctic & \\
\hline aggregatus & Riser, 2000 & Massachusetts, US Atlantic coast & (6) \\
\hline pettiboneae & Riser, 2000 & New England, US Atlantic coast & (7) \\
\hline intermedius comb. nov. & (Uchida, 2004) & Kii Peninsula, Japan & $(8)$ \\
\hline itoi & Uchida, 2004 & Hokkaido, Japan & \\
\hline mahensis & n.sp. & Indian Ocean, Seychelles & \\
\hline
\end{tabular}

occupied by M. pacificus (Friedrich, 1956) (see above), the species is provided here with a new name: M. japonicus nom.nov Yamanishi, 1984.

6. Microphthalmus aggregatus Riser, 2000 is one of the three species, into which Riser (2000) referred the type material of Podarke aberrans Webster and Benedict, 1887 (see remarks under M. pettiboneae).
Riser's new species is probably identical with the North American M. cf. similis Bobretzky, 1870, which Westheide and Rieger (1978) and Westheide (1979) investigated from the Outer Banks off the North Carolina coastline. In addition, the identity of $M$. aggregatus with specimens from north European seas (so far recorded as M. similis, Westheide (1967, 
p. 133); Hartmann-Schröder and Stripp (1968); Hartmann-Schröder (1996, p. 147) cannot be excluded, even though they differ in minor characters, for example, number of fimbriae of the anal plate. Finally, it could not yet be corroborated that they are identical with material from the Black Sea (Bobretzky 1870; Marinov 1963) and the Mediterranean Sea (La Greca 1950). It is not unlikely that all these populations belong to separate species.

7. The chaetation of M. pettiboneae Riser, 2000 and the European M. aberrans. (Webster and Benedict, 1887) sensu Westheide (1967), respectively, appears to be almost identical with that of $M$. pseudoaberrans Campoy and Viéitez, 1982. The latter differs only in total body length (twice as long), in relative length of the dorsal cirri and in minor details of the shape of the anal plate. This makes it difficult or nearly impossible to differentiate between immature specimens of these species. Unfortunately, nothing is known about the genital structures of the south European species, while the unpaired protrusible male copulatory organ is such a key character in the north European M. aberrans (Westheide 1967). Since, however, clear differences could also be found by molecular methods (Meyer 1998, unpublished), the validity of $M$. pseudoaberrans cannot be doubted. This is also supported by the fact that the latter species was exclusively recorded in coastal areas of southern Europe so far (Spain, Portugal and at various places of the Mediterranean Sea, in particular (Meyer 1998; Parapar et al. 2004).

8. Though recognizing a close correspondence with Microphthalmus, Uchida (2004) erected a new genus for Uncopoda intermedia Uchida, 2004 because of the presence of compound claw chaetae in the neuropodia of the first chaetiger. However, the characteristic anal plate between two dorsally positioned anal cirri of this species is a diagnostic feature of Microphthalmus. Also, the notopodial pectinate (lyrate) chaeta proves the species to belong to a subgroup of this taxon. In contrast, claw-like or hook-like chaetae of varying shape are specific characters of several Microphthalmus species. They may be linked with a commensal or parasitic life history of the respective species (e.g. Westheide 1982).

9. All type specimens of Microphthalmus stocki lack posterior ends, thus making it impossible to decide whether they possess an anal plate, the most characteristic feature of the genus. It is obvious, however, that they differ from Microphthalmus in several characters, for example, antennae, palps, tentacular and dorsal cirri feature distinctly separated basal parts (palpophores, cirrophores); the median antenna has an extremely frontal position; pigmented eye spots are absent; a pectinate notopodial chaeta does not occur; there are two furcate chaetae, so far unknown in any true Microphthalmus species. It must be assumed, therefore, that M. stocki (HartmannSchröder, 1980) belongs to another genus of yet unknown identity.

10. The incomplete holotype of Microphthalmus sczelkowii longisetosa (Hartmann-Schröder 1974a) does not allow a determination of its definitive taxonomic position. 
Morphological key for the species of Microphthalmus Mescznikow, 1865

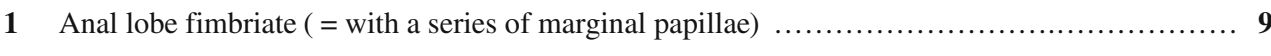

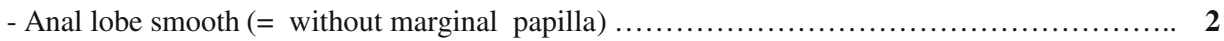

2 All chaetae simple, in both notopodia and neuropodia

simplicichaetosus

Westheide and Purschke, 1992

- Neuropodial chaetae predominantly heterogomph compounds .

3 Subdistally serrated (= pectinate) chaeta in both the neuropodial and the notopodial chaetal bundles (differently shaped) urofimbriatus Alikunhi,1948

- Pectinate chaeta only in neuropodia. Notopodia with identical exclusively simple chaetae

hartmanae Westheide, 1977

japonicus Yamanishi, 1984

(see under Taxonomic remarks)

- Pectinate chaetae exclusively notopodial

412 or more simple notopodial chaetae, including a pectinate one 5

-Less than ten notopodial chaetae.

5 Dorsal parapodial cirri distinctly extending beyond neuropodial lobes fragilis Bobretzky, 1870

- Dorsal cirri only slightly longer than neuropodial lobes

itoi Uchida, 2004

aberrans

(Webster and Benedict, 1887)

sensu Riser (2000)

6 Five notopodial chaetae.

- Four or less than five notopodial chaetae. Male copulatory organs with stylet bundle.

7 Notopodial chaetal bundle including one (or two) simple hooks

indefatigatus Westheide,1974

- without hook-shaped chaetae

bermudensis Westheide,1973

8 Three notopodial chaetae including one pectinate one and one acicula

mahensis n.sp.

- two notochaetae including one pectinate one and one acicula

similis Bobretzky, 1870

aggregatus Riser, 2000

9 Unpaired median prostomial antenna present 
10 Claw or hook-shaped compound neurochaetae in chaetigers

of the anterior end

-without hook-shaped neurochaetae

riojai Reish, 1968

biantennatus $\mathrm{Wu}$,

Zhao and

Westheide, 1993

(For diagnostic features see original descriptions.)

11 Anal lobe hemispherical

intermedius (Uchida, 2004)

-Anal lobes modified, lateral edges bent dorsally into a spiral hamosus Westheide,1982 fold

12 Anal lobe smooth, furcated. Two notochaetae

bifurcatus Hartmann-Schröder, including a pectinate one

-Anal lobe hemispherical or with slight notch in the middle...

13 Notopodia with four or more chaetae.

- Notopodia with three or two chaetae only....

14 About five simple straight notochaetae

-Notochaetae four to five hooked spines

-Notochaetae with one hook from $6^{\text {th }}$ to $9^{\text {th }}$ chaetiger backwards

15 Notopodia without pectinate (=lyriate) chaetae monilicornis Hartmann-Schröder, 1962

hystrix Fournier, 1991

onychophorus Westheide, 1994

aciculata Hartmann-

Schröder, 1962

- Notopodia with three chaetae, including one pectinate and one acicula per bundle. (For diagnostic features see original descriptions.)

\author{
"aberrans" \\ (north European species, \\ sensu Westheide(1967)) \\ ancistrosylliiformis \\ Hartmann-Schröder, 1962 \\ tyrrhenicus \\ Zunarelli Vandini, 1967 \\ paraberrans \\ Hartmann-Schröder, 1982 \\ westheidei \\ Hartmann-Schröder, 1982 \\ pseudoaberrans \\ Campoy and Viéitiez, 1982 \\ pettiboneae \\ Riser, 2000
}


16 Male copulatory organs suctorial.....

-Male copulatory organs tubular and cuticular

-Male copulatory organs absent or unknown

17 Total body length less than $1.5 \mathrm{~mm}$

- Body length more than $3 \mathrm{~mm}$ arenarius Westheide, 1973

sczelkowii Mecznikow, 1865

ephippiophorus Clausen, 1986

18 Extended filiform body appendages; dorsal cirri several times longer than body width. Copulatory tubes with proximal cuff-like collar

listensis Westheide, 1967

carolinensis Westheide and

Rieger, 1987

nahantensis Westheide and

Rieger, 1987

(For diagnostic features see Westheide and Rieger (1987)).

- Dorsal cirri as long or somewhat longer than neuropodial lobes. Copulatory tubes without proximal collar.....

19

Copulatory tubes with narrow distal part

-Copulatory tubes funnel-shaped, with long distal tip

20
Copulatory tubes absent or unknown

(For diagnostic features, see original descriptions.) riseri Westheide, 1984

antarcticus Bick, 1997

southerni Westheide, 1967

coustalini Fournier, 1991
Acknowledgments Special thanks are due to Dr. Gunde Rieger (Innsbruck), who kindly corrected the English text, Dr. Sergio Sallazar-Vallejo (Chetumal), whose comments considerably improved the manuscript, Birte Pahlmann (Osnabrück), Dr. Marcus Böggemann (Vechta) and Dr. Dieter Fiege for various help.

\section{References}

Alikunhi KH (1948) On a new hermaphrodite species of Microphthalmus (Polychaeta-Hesionidae) from the sandy beach, Madras. J Roy Soc Bengal Sci 14:17-25

Bick A (1997/98) Microphthalmus antarticus sp.n. ("Polychaeta", Phyllodocida, Hesionidae) from intertidal coastal areas of King George Island, South Shetlands, Antarctica, with a description of the neuropodial setation of further Microphthalmus species. Zool Anz 236:133-138

Bobretzky N (1870) On the fauna of the Black Sea (In Russian). Kiev Odsh Estet Zap 1:1-26

Böggemann M, Westheide W (2004) Interstitial Syllidae (Annelida: Polychaeta) from Mahé (Seychelles). J Nat Hist 38: 403-446

Böggemann M, Hessling R, Westheide W (2003) Horizontal distribution pattern of the syllid Fauna (Annelida: Polychaeta) in the fringing reef lagoon of Anse Forbans (Seychelles, Mahé) and redescription of the abundant Streptosyllis aequiseta. Hydrobiologia 496:17-26

Campoy A, Viéitez JM (1982) Microphthalmus pseudoaberrans n.sp. (Polychaeta, Microphthalminae) de la rías bachas gallegas. Actas del II Simposio Ibérico de Estudios del Bentos Marino, San Sebastián, vol 3, pp 159-164

Clausen C (1986) Microphthalmus ephippiophorus sp.n. (Polychaeta: Hesionidae) and two other Microphthalmus species from the Bergen area, Western Norway. Sarsia 71:177-191

Fournier JA (1991) New species of Microphthalmus (Polychaeta: Hesionidae) from the Pacific Northwest. Bull Mar Sci 48:208-213

Friedrich H (1956) Mitteilungen über neue und wenig bekannte Polychaeten aus Mittel- und Südamerika. Senckenb biol 37:57-68

Hartman O (1939) New species of polychaetous annelids from Southern California with a discussion on the host of one of them. Allan Hancock Pac Exped 7:157-172

Hartmann-Schröder G (1959) Zur Ökologie der Polychaeten des Mangrove-Estero-Gebietes von El Salvador. Beitr Neotrop Fauna 1:69-183

Hartmann-Schröder G (1962a) Zweiter Beitrag zur Polychaetenfauna von Peru. Kiel Meeresf 18:109-147

Hartmann-Schröder G (1962b) Die Polychaeten des Eulitorals. In: Hartmann-Schröder G, Hartmann G (eds) Zur Kenntnis des Eulitorals der chilenischen Pazifikküste und der argentinischen Küste Südpatagoniens unter besonderer Berücksichtigung der 
Polychaeten und Ostracoden. Mit Hamb Zool Mus Inst 60, Suppl:57-270

Hartmann-Schröder G (1974a) Zur Kenntnis des Eulitorals der afrikanischen Westküste zwischen Angola und Kap der Guten Hoffnung und der afrikanischen Ostküste von Südafrika und Mocambique unter besonderer Berücksichtigung der Polychaeten und Ostracoden. Teil II. Die Polychaeten des Untersuchungsgebietes. Mitt Hamb Zool Mus Inst Ergänz 69:95-228

Hartmann-Schröder G (1974b) Polychaeten von Expeditionen der „Anton Dohrn“ in Nordsee und Skagerrak. Veröff Inst Meeresforsch Bremerh 14:169-274

Hartmann-Schröder G (1980) Amsterdam expeditions to the Westindian Islands, Report 9. Die Polychaeten der Amsterdam-Expeditionen nach Westindien. Bijd Dierk 50:387-401

Hartmann-Schröder G (1982) Teil 8. Die Polychaeten der subtropisch-antiborealen Westküste Australiens (zwischen Cervantes im Norden und Cape Naturaliste im Süden). In: Hartmann-Schröder G und Hartmann G, Zur Kenntnis des Eulitorals der autralischen Küsten unter besonderer Berücksichtigung der Polychaeten und Ostracoden. Mitt Hamb Zool Mus Inst 79:51-118

Hartmann-Schröder G, Stripp K (1968) Beiträge zur Polychaetenfauna der Deutschen Bucht. Veröff Inst Meeresforsch Bremerh 11:1-24

Hartmann-Schröder G (1996) Annelida, Borstenwürmer, Polychaeta. Tierwelt Deutschlands und der angrenzenden Meeresteile. 58, 2. Aufl. Gustav Fischer, Jena

La Greca M (1950) Sulla presenca nel Mediterraneo di Lycastoides pontica (Bobr.), Microphthalmus fragilis Bobr. E M. similis Bobr., (Annelida Polychaeta). Annuario dell'Istituto e Museo di Zoologia della Università di Napoli 2:1-16

Laubier L (1967) Adaptations chez les Annélides Polychètes interstitielles. Ann bio Paris 6:1-16

Marinov T (1963) Über die Polychaetenfauna der Sandbiozönose vor der Bulgarischen Schwarzmeerküste. Bull Inst Centr Rech Sci Pisc Péch Varna 3:61-78

Mecznikow E (1865) Beiträge zur Kenntnis der Chaetopoden. $Z$ wiss Zool 15:334-335

Meyer J (1998) Populationsgenetische Untersuchung mit RAPD-PCR an einem europäischen Microphthalmus-Artenkomplex (Polychaeta, Hesionidae). Diplom-thesis, University of Osnabrück, Germany

Parapar J, Besteiro C, Moreiro J (2004) Familia Hesionidae Grube, 1850. In: Polychaeta I, Viétez JM, Alos C, Parapa J, Besteiro C, Moreira J, Nùnez J, Laborda J, San Martin G, Annelida. Fauna Ibérica. Ramos MA et al (eds) Museo Nacional de Cincias Naturales. SCIC, Madrid, pp 210-267

Pettibone MH (1963) Marine polychaete worms of the New England region. 1. Aphroditidae through Trochochaetidae. Bull US Nat Mus 227:1-356

Pleijel F, Dahlgren T (1998) Position and delineation of Chrysopetalidae and Hesionidae (Annelida, Polychaeta, Phyllodocida). Cladistics 14:129-150

Purschke G (1997) Ultrastructure of nuchal organs in polychaetes (Annelida)—new results and review. Act Zool (Stockholm) 78:123-143

Reish DJ (1968) A biolological survey of Bahia de Los Angeles, Gulf of California, Mexico. II. Benthic polychaetous annelids. Trans San Diego Soc Nat Hist 15:67-106

Riser NW (2000) Podarke aberrans Webster \& Benedict, 1887resolution, with descriptions of two new species in the genus Microphthalmus (Annelida: Polychaeta). Proc Biol Soc Wash 113:514-525

Rouse GW, Pleijel F (2001) Polychaetes. Oxford University Press, New York, $354 \mathrm{pp}$

Southern R (1914) Clare Island survey archiannelida and polychaeta. Proc R Irish Acad 31:1-160
Uchida H (2004) Hesionidae (Annelida, Polichaeta) from Japan. I Kuroshio Biosphere 1:27-92

Webster HE, Benedict JE (1887) The Annelida Chaetopoda from Eastport, Maine. Ann Rep US Com Fish Fisheries, Washington 1985:707-758

Westheide W (1967) Monographie der Gattungen Hesionides Friedrich und Microphthalmus Mecznikow (Polychaeta, Hesionidae). Z Morph Tiere 61:1-159

Westheide W (1973) Zwei neue interstitielle Microphthalmus-Arten (Polychaeta) von den Bermudas. Mikrofauna Meeresb 14:1-16

Westheide W (1974) Interstitielle Fauna von Galapagos XI Pisionidae, Hesionidae, Pilargidae, Syllidae (Polychaeta). Mikrofauna Meeresb 44:1-146

Westheide W (1977) Phylogenetic systematics of the genus Microphthalmus (Hesionidae) together with a description of M. hartmanae nov sp. In: Reish DJ, Fauchald K (eds) Essays on polychaetous annelids in memory of Dr. Olga Hartman. Allan Hancock Foundation, Los Angeles, pp 103-113

Westheide W (1979) Ultrastruktur der Genitalorgane interstitieller Polychaeten II Männliche Kopulationsorgane mit intrazellulären Stilettstäben in einer Microphthalmus-Art. Zool Scr 8:111-118

Westheide W (1982) Microphthalmus hamosus sp.n. (Polychaeta, Hesionidae) - an example of evolution leading from the interstitial fauna to a macrofaunal interspecific relationship. Zool Scr 11:189-193

Westheide W (1988) XV. Genital Organs. In: Westheide W, Hermans CO (eds) The Ultrastructure of Polychaetes. Microfauna Mar 4:263-279

Westheide W (1994) Two new Microphthalmus species (Polychaeta, Hesionidae) from intertidal sand beaches in New Zealand and Chile. Microfauna Mar 9:45-53

Westheide W (2000a) Ikosipodoides seychellensis, a new genus and species of interstitial polychaetes (Dorvilleidae) from the island of Mahé, Indian Ocean. Cah Biol Mar 41:19-23

Westheide W (2000b) Mahesia ammophila, a new genus and species of interstitial hesionid (Annelida: Polychaeta) from the Indian Ocean. Proc Biol Soc Wash 113:644-651

Westheide W (2001) Laubierpholoe indooceanica, a new interstitial polychaete (Pholoidae) from South India and the Seychelles. Cah Biol Mar 42:327-332

Westheide W, Hass-Cordes E (2001) Molecular taxonomy: description of a cryptic Petitia species (Polychaeta: Syllidae) from the island of Mahé (Seychelles, Indian Ocean) using RAPD markers and ITS2 sequences. J Zool Syst Evol Res 39:103-111

Westheide W, Purschke G (1992) Microphthalmus simplicichaetosus (Annelida, Polychaeta), a new hesionid from the northwestern American Pacific coast with exclusively simple chaetae. Proc Biol Soc Wash 105:132-135

Westheide W, Rieger RM (1987) Systematics of the Microphthalmuslistensis-species-group (Polychaeta, Hesionidae): facts and concepts for reconstruction of phylogeny and speciation. Z Zool Syst Evolut forsch 25:12-39

Westheide W, Schmidt H (2003) Cosmopolitan versus cryptic meiofaunal polychaete species: an approach to a molecular taxonomy. Helgoland Mar Res 57:1-6

Wu B, Zhao J, Westheide W (1993) A new species of meiofauna polychaete Microphthalmus from Yellow Sea. Acta Zootax Sin 18:1-3

Yamanishi R (1984) Interstitial polychaetes of Japan. III. Six species of Microphthalminae (Hesionidae) including a new species and three new subspecies. Publ Seto Mar Biol Lab 29:323-332

Zunarelli Vandini R (1967) Una nuova specie di Microphthalmus delle coste livornesi (Polychaeta Hesionidae). Arch Zool Ital $52: 217-220$ 